\title{
VIRUSINĖS C HEPATITO INFEKCIJOS IR 2 TIPO CUKRINIO DIABETO KOMORBIDIŠKUMAS
}

\author{
Tomas Masilionis, Paulius Vargalis, Raimondas Kiltinavičius \\ Lietuvos sveikatos moksly universiteto Medicinos akademijos Medicinos fakultetas
}

Raktažodžiai: $\mathrm{CD}$, cukrinis diabetas, $\mathrm{C}$ hepatitas, infekcija.

\section{Santrauka}

$\mathrm{C}$ hepatitas yra virusinè infekcija, kuri sukelia kepenų pažeidimą. Šios ligos eiga pradžioje besimptomè, tad žmogus, nesijausdamas sergantis, gali ja užkrèsti kitus. Jei užsikrètus šiuo virusu sergama besimptome ligos forma daugiau nei 6 mènesius, ji dažniausiai pereina ị lètinę, kuri gali iš lèto progresuoti ị kepenų cirozę ir sukelti hepatocitų karcinogenezę. Taip gali susiformuoti hepatoceliulinė karcinoma (HCC). Progresuodama C hepatito viruso (HCV) infekcija gali paveikti kitas gretutines ligas, ar netgi sukelti naujų. Viena iš tokių ligų yra 2 tipo cukrinis diabetas (CD2). Darbo tikslas - išsiaiškinti $C$ hepatito viruso sukeltos infekcijos ir 2 tipo cukrinio diabeto sąsajas. Straipsnių paieška atlikta $\mathrm{Pu}-$ bMed, BioMed Central duomenų bazėse. Naudotos raktažodžių kombinacijos: diabetes mellitus, hepatitis $\mathrm{C}$ virus extrahepatic manifestations. Rezultatai atskleidè, kad sergantiems HCV sukelta ciroze ir hepatoceliuline karcinoma, CD2 rizika didesnè. HCV labiau paplitęs tarp sergančiujų CD2. Manoma, kad CD2 išsivystymas HCV sergantiems pacientams siejamas su $\beta$ ląsteliụ disfunkcija arba autoimuniniu kasos pažeidimu. Rezistentiškumas insulinui skatina sergančiujų HCV infekcija kepenų pažaidos bei HCC karcinomos vystymąsi, nepriklausomai, išsivystęs CD2 ar ne. Sergantiems cukriniu diabetu ir HCV turintiems pacientams ženkliai didèja HCC progresavimo rizika, kuri blogina gyvenimo kokybę. Svarbi kuo ankstyvesnè šių ligų diagnostika ir profilaktika, nutukimo, dislipidemijos korekcija bei alkoholio vartojimo ribojimas. I prevencinius patikrinimus turètų būti dažniau įtrauktas gliukozès kiekio matavimas kraujyje bei periodinis gliukozės tolerancijos mėginys. Tai sumažintų ne tik CD2, bet ir HCC išsivystymo riziką. Nustatyta, kad sėkmingas HCV gydymas gali sumažinti susirgimo cukriniu diabetu riziką. Ilgą laiką sẻkmingai gydant interferonu ar tiesiogiai veikian- čiais priešvirusiniais preparatais, pastebèta CD2 regresija. Lyginant HCV gydymą interferonais ir tiesiogiai veikiančiais priešvirusiniais preparatais, geresnè CD2 kontrolè gauta, kuomet pacientai buvo gydomi tiesiogiai veikiančiais priešvirusiniais preparatais.

\section{Ivadas}

C hepatito viruso (HCV) infekcijos reikšmè kepenų pažaidai žinoma seniai. Šio viruso sukelta infekcija dažniausiai pasižymi lètine, silpnai išreikšta eiga, o ūmus $\mathrm{C}$ hepatitas yra retesnis $[1,2]$. Dažniausiai lètinė HCV infekcija nustatoma tiriant profilaktiškai pacientus, esančius rizikos grupėse, kraujo donorus arba jau pasireiškus komplikacijoms $[3,4]$. Seniai išnagrinètas ir patvirtintas HCV infekcijos ir kepenu cirozės bei hepatoceliulinès karcinomos (HCC) ryšys $[5,6]$, tačiau atsiranda duomenų, jog šiam virusui būdinga ir ekstrahepatinių organų pažaida bei ryšys su kitų organų sistemų ligomis [7]. Viena iš tokių ligų yra 2 tipo cukrinis diabetas (CD2).

Darbo tikslas - išsiaiškinti $C$ hepatito viruso sukeltos infekcijos ir 2 tipo cukrinio diabeto sąsajas.

\section{Tyrimo medžiaga ir metodai}

Buvo ieškoma straipsnių moksliniuose žurnaluose, mokslinių darbų, atliktų tyrimų rezultatų šiose duomenų bazėse: PubMed, BioMed Central. Naudotos raktažodžių kombinacijos: diabetes mellitus, hepatitis $\mathrm{C}$ virus extrahepatic manifestations.

\section{Tyrimo rezultatai}

HCV ir CD2 ryšys. Literatūroje teigiama, kad HCV infekcija susijusi su padidejusia CD2 išsivystymo rizika, nepriklausomai nuo susijusios kepenų ligos ir jos sunkumo - tiek sergantiems hepatoceliuline karcinoma (HCC), tiek HCV sukelta ciroze [1,2]. Teigiama, kad CD2 rizika didesnè pacientams, sergantiems HCV sukelta ciroze, nei HCV sukelta hepatoceliuline karcinoma. Be to, pats HCV labiau paplitęs tarp sergančiujų CD2, o HBV infekcijos paplitimas yra tolygus tarp sergančiujų ir nesergančiujų CD2. Rezul- 
tatai rodo statistiškai reikšmingą HCV lètinès infekcijos ir CD2 ryšį [9].

Literatūroje nurodoma, kad CD2 pasireiškimo virusiniai veiksniai nèra absoliutūs. CD2 pasireiškimą lemia virusinių veiksnių ir jau esamų būklių (tokių, kaip pirminis ar antrinis imunodeficitas, genetinè predispozicija, gyvensena, gretutinès ligos derinys [10]. Pacientams, kuriems dèl HCV persodintos kepenys, didesnè cukrinio diabeto rizika po transplantacijos, palyginti su tais, kuriems transplantacija atliekama dèl kitų būklių [9]. Daugelis tyrimų, ịvertinusių $\mathrm{HCV}$ ir CD2 ryši, rodo, kad rezistentiškumas insulinui vaidina labai svarbų vaidmeni [11], tačiau konkretaus patofiziologinio mechanizmo nèra išaiškinta, o kitu tyrimų metu nustatyta, jog CD2 išsivystymas HCV pacientams siejamas su $\beta$ ląstelių disfunkcija arba autoimuniniu kasos pažeidimu $[3,5]$. Patofiziologinio mechanizmo išaiškinimas leistų suprasti CD2 išsivystymo kelią ir padètų atrinkti išskirtinio demesio ir profilaktinių patikrų reikalingas pacientų grupes ir turètų svarbios reikšmès, pasirenkant gydymo taktiką.

Autorių teigimu, egzistuoja ir atgalinis ryšys. Rezistentiškumas insulinui skatina sergančiujų $\mathrm{HCV}$ infekcija kepenų pažaidos bei HCC karcinomos vystymąsi, nepriklausomai, CD2 jau išsivystęs ar ne, o sergantiems cukriniu diabetu ir turintiems HCV, HCC progresavimo rizika kur kas didesné, nei nesergančių cukriniu diabetu HCV pacientu [10]. Šių abiejų ligų komirbidiškumas sudaro ydingą ratą, nes jos viena kitą skatina. Nurodoma, kad cukrinis diabetas turi selektyvų poveikị HCC raidai $[2,7,8]$. Ryšys tarp HCV infekcijos ir CD2 išsivystymo didina prevencinių priemonių kūrimo poreikị. Antriné prevencija turètų būti skiriama sergantiesiems HCV, siekiant keisti jų gyvenimo būdą, taip mažinant rezistentiškumą insulinui ir CD2 išsivystymo riziką $[9,10]$. I profilaktinius tikrinimus turètų būti ịtrauktas gliukozès kiekio matavimas kraujyje bei periodinis gliukozès tolerancijos méginys. Nutukimo, dislipidemijos korekcija bei alkoholio vartojimo ribojimas sumažintų CD2 ir HCC išsivystymo riziką [17].

Priešinga nuomonè teigia, kad HCV ir CD2 ryšys pastebètas dèl to, kad CD2 pacientams daug dažniau atliekamos ìvairios manipuliacijos, pažeidžiančios odos barjerą, nei bendroje populiacijoje [10]. Daugumoje šị ryšị nagrinejjusių tyrimų nebuvo atsižvelgta, ar HCV pacientai jau serga kepenų ciroze, kuri pati gali sukelti rezistentiškumą insulinui bei paskatinti CD2 vystymąsi [18].

HCV gydymo įtaka CD2. Sèkmingas HCV gydymas gali sumažinti cukrinio diabeto riziką. Ilgą laiką sẻkmingai gydant interferonu, ar tiesiogiai veikiančiais priešvirusiniais preparatais, pastebeta CD2 regresija $[11,12]$. Nors ši koreliacija galima ir dèl gerẻjančios kepenų būklès, CD2 regresija ịvyksta ne dèl virusinių veiksnių, o dèl kepenų būklès. S. Fabiani ir kt. [21] atliktoje metaanalizèje gauta, kad CD2 daug dažniau pasireiškè tiems HCV pacientams, kuriems jau buvo prasidejjusi cirozè. Teigiama, kad dauguma autorių, nagrinèdami ši ryšį, neįtraukẻ tokių svarbių veiksnių, kaip gyvensena, nutukimas, gliukozès kiekis ir rezistencija insulinui iki HCV infekcijos, šeimine CD2 anamnezè. Dèl šios priežasties mažèja patikimų straipsnių ir tyrimų, todèl šio ryšio buvimui patvirtinti reikalingi tolimesni tyrimai.

Buvo tirtas HCV ir CD2 sergančių pacientų atsakas ị tam tikrus gydymo režimus. C. Carnovale ir kt. [22] atliktoje metaanalizèje tirta, kaip kinta šių pacientų glikeminiai rodikliai, taikant ịvairius gydymo metodus ir esant skirtingam atsakui i juos. Pacientams, kurių diabetas buvo koreguojamas tiek insulinu, tiek hipoglikemizuojančias vaistais, tačiau jų HCV gydymas nebuvo sẻkmingas, serumo gliukozės ir HbA1c korekcija buvo sudetinga. Nurodoma, kad daugumai pacientų šių rodiklių tinkamai pakoreguoti nepavyko. Atvejais, kai HCV gydymas buvo sėkmingas, CD2 kontrolè taip pat buvo pasiekta. Lyginant HCV gydymą interferonais ir tiesiogiai veikiančiais priešvirusiniais preparatais, geresnè CD2 kontrolė gauta gydant tiesiogiai veikiančiais priešvirusiniais preparatais. Esant šiai teigiamai CD2 dinamikai, gydant tiesiogiai veikiančiais priešvirusiniais preparatais, būtinas kruopštus paciento stebėjimas, nes mažejjant bendram organizmo rezistentiškumui insulinui, galimos hipoglikeminès būklès.

\section{Išvados}

$\mathrm{HCV}$ virusinè infekcija turi įtakos rezistentiškumo insulinui ir CD2 pasireiškimui. Dèl tyrimų stokos ir neatsižvelgimo i jau esamus $\mathrm{CD} 2$ rizikos veiksnius $\mathrm{HCV}$ infekuotiems pacientams, būtinas nuodugnesnis šio ryšio ištyrimas. CD2 pasireiškimas statistiškai reikšmingai dažnesnis HCV pacientams, nei bendroje populiacijoje. Sèkmingas HCV infekcijos gydymas turi teigiamą efektą CD2 eigai. Geriausias efektas gaunamas $\mathrm{HCV}$ gydant tiesiogiai veikiančiais priešvirusiniais preparatais.

\section{Literatūra}

1. Kamal SM. Acute hepatitis C: a systematic review. Am J Gastr 2008;103:1283-1297.

https://doi.org/10.1111/j.1572-0241.2008.01825.x

2.Thein HH, Yi Q, Dore GJ, et al. Estimation of stage-specific fibrosis progression rates in chronic hepatitis $\mathrm{C}$ virus infection: a meta-analysis and meta-regression. Hepatolol 2008; 48:418-431. https://doi.org/10.1002/hep.22375

3. Coward S, Leggett L, Kaplan GG, et al. Cost-effectiveness of screening for hepatitis $\mathrm{C}$ virus: a systematic review of economic evaluations. BMJ Open 2016;6(9):e011821.

https://doi.org/10.1136/bmjopen-2016-011821 
4. Tang W, Chen W, Amini A, et al. Diagnostic accuracy of tests to detect hepatitis $\mathrm{C}$ antibody: a meta-analysis and review of the literature. BMC Infect Dis 2017;17(Suppl 1):695. https://doi.org/10.1186/s12879-017-2773-2

5. Walker AJ, Peacock CJ, Pedergnana V, et al. Host genetic factors associated with hepatocellular carcinoma in patients with hepatitis C virus infection: a systematic review. J Viral Hepat 2018;25:442-456.

https://doi.org/10.1111/jvh.12871

6. de Martel C, Maucort-Boulch D, Plummer M, et al. World-wide relative contribution of hepatitis $\mathrm{B}$ and $\mathrm{C}$ viruses in hepatocellular carcinoma. Hepat 2015;62:1190-1200.

https://doi.org/10.1002/hep.27969

7. Younossi Z, Park H, Henry L, et al. Extrahepatic manifestations of hepatitis C: a meta-analysis of prevalence, quality of life, and economic burden. Gastroenterol 2016;150:1599-1608. https://doi.org/10.1053/j.gastro.2016.02.039

8. Wang P, Kang D, Cao W, et al. Diabetes mellitus and risk of hepatocellular carcinoma: a systematic review and meta-analysis. Diabetes Metab Res Rev 2012;28:109-122.

https://doi.org/10.1002/dmrr.1291

9. Fiorino S, Bacchi-Reggiani L, De Biase D, et al. Possible association between hepatitis $\mathrm{C}$ virus and malignancies different from hepatocellular carcinoma: a systematic review. World J Gastroenterol 2015;21:12896-12953. https://doi.org/10.3748/wjg.v21.i45.12896

10. Guo X, Jin M, Yang M, et al. Type 2 diabetes mellitus and the risk of hepatitis $\mathrm{C}$ virus infection: a systematic review. Sci Rep 2013;3:2981. https://doi.org/10.1038/srep02981

11. Hung CH, Lee CM, Lu SN. Hepatitis C virus-associated insulin resistance: pathogenic mechanisms and clinical implications. Expert Rev Anti Infect Ther 2011;9:525-533. https://doi.org/10.1586/eri.11.33

12. Kawaguchi T, Ide T, Taniguchi E, et al. Clearance of HCV improves insulin resistance, beta-cell function, and hepatic expression of insulin receptor substrate 1 and 2. J Gastroenterol 2007; 102:570-576. https://doi.org/10.1111/j.1572-0241.2006.01038.x

13. Saran U, Humar B, Kolly P, et al. Hepatocellular carcinoma and lifestyles. J Hepatol 2016;64:203-214. https://doi.org/10.1016/j.jhep.2015.08.028

14. Wang YG, Wang P, Wang B, et al. Diabetes mellitus and poorer prognosis in hepatocellular carcinoma: a systematic review and meta-analysis. PLoS One 2014;9(5): e95485. https://doi.org/10.1371/journal.pone.0095485

15. Guo X, Jin M, Yang M, et al. Type 2 diabetes mellitus and the risk of hepatitis $\mathrm{C}$ virus infection: a systematic review. Sci Rep 2013;3:2981. https://doi.org/10.1038/srep02981

16. Basseri B, Yamini D, Chee G, et al. Comorbidities associated with the increasing burden of hepatitis $\mathrm{C}$ infection. Liver Int 2010;30:1012-1018.

https://doi.org/10.1111/j.1478-3231.2010.02235.x

17. Wang C, Wang X, Gong G, et al. Increased risk of hepatocellular carcinoma in patients with diabetes mellitus: a systematic review and meta-analysis of cohort studies. Int J Cancer 2012;130:1639-1648.

https://doi.org/10.1002/ijc.26165

18. Manne V, Akhtar E, Saab S. Cirrhosis regression in patients with viral hepatitis B and C a systematic review. J Clin Gastroenterol 2014;48:e76-e84.

https://doi.org/10.1097/MCG.0000000000000162

19. Manthravadi S, Paleti S, Pandya P. Impact of sustained viral response postcurative therapy of hepatitis $\mathrm{C}$-related hepatocellular carcinoma: a systematic review and meta-analysis. Int $\mathrm{J}$ Cancer 2017;140:1042-1049.

https://doi.org/10.1002/ijc.30521

20. Bang CS, Song IH. Impact of antiviral therapy on hepatocellular carcinoma and mortality in patients with chronic hepatitis $\mathrm{C}$ : systematic review and meta-analysis. BMC Gastroenterol 2017;17:1-19.

https://doi.org/10.1186/s12876-017-0606-9

21. Fabiani S, Fallahi P, Ferrari SM, et al. Hepatitis C virus infection and development of type 2 diabetes mellitus: systematic review and meta-analysis of the literature. Rev Endocr Metab Disord 2018;19:405-420.

https://doi.org/10.1007/s11154-017-9440-1

22. Carnovale C, Pozzi M, Dassano A, et al. The impact of a successful treatment of hepatitis $\mathrm{C}$ virus on glyco-metabolic control in diabetic patients: a systematic review and metaanalysis. Acta Diabetol 2019;56:341-354. https://doi.org/10.1007/s00592-018-1257-1

\section{COMORBIDITY OF HEPATITIS C VIRUS INFECTION AND TYPE 2 DIABETES T. Masilionis, P. Vargalis, R. Kiltinavičius}

Keywords: diabetes mellitus; diabetes; hepatitis C; infection. Summary

Hepatitis $\mathrm{C}$ is a viral infection that causes liver damage. This disease is asymptomatic at first and a person may not know or feel that they are infected and infect others. If person becomes infected with this virus and suffer from an asymptomatic form of the disease for more than 6 months, then the disease usually progresses to a chronic form. Untreated chronic hepatitis $\mathrm{C}$ infection usually slowly progresses to cirrhosis of the liver and may induce carcinogenesis of hepatocytes which leads to development of hepatocellular carcinoma. As the disease progresses, it may affect other comorbidities or even induce some. One such disease is type 2 diabetes mellitus. The risk of type 2 diabetes mellitus is thought to be higher in patients with HCV-induced cirrhosis and HCV-induced hepatocellular carcinoma. In addition, HCV itself is more common among patients with diabetes mellitus. Type 2 diabetes mel- 
litus development in HCV patients is also thought to be associated with $\beta$-cell dysfunction or autoimmune pancreatic injury. Insulin resistance promotes the development of liver damage and hepatocellular carcinoma in patients with HCV infection, whether or not they have already developed type 2 diabetes mellitus, and patients with diabetes and HCV have a significantly increased risk of hepatocellular carcinoma to progress, which impairs quality of life. Therefore, it is important to diagnose and prevent these diseases as early as possible. Preventive tests should include more frequent blood glucose measurements and periodic glucose tolerance testing. Also correction of obesity, dyslipidemia and restriction of alcohol consumption. This would not only reduce the risk of type 2 diabetes mellitus development but also reduce the risk of development of hepatocellular carcinoma. It is found that successful HCV treatment can reduce the risk of diabetes. Type 2 diabetes mellitus regression has been observed with long-term successful treatment of $\mathrm{HCV}$ with interferon or direct-acting antiviral agents. Compa- ring $\mathrm{HCV}$ treatment with interferons and direct-acting antivirals, better glycemic control was obtained when patients were treated with direct-acting antivirals.

Conclusions. HCV viral infection affects the development of insulin resistance and diabetes mellitus type 2 . Due to the lack of studies and the lack of consideration of pre-existing diabetes mellitus type 2 risk factors in $\mathrm{HCV}$-infected patients, further investigation of this relationship is required. However, the incidence of diabetes mellitus type 2 is statistically significantly higher in HCV patients than in the general population. Successful treatment of HCV infection has a positive effect on the course of diabetes. The best effect is obtained by treating $\mathrm{HCV}$ with direct-acting antiviral drugs.

Correspondence to: tomas.masilionis95@gmail.com

Gauta 2020-05-25

\section{KVIEČIAME PRENUMERUOTI „SVEIKATOS MOKSLŲ“ ŽURNALĄ 2021 METAIS!}

Žurnalas „Sveikatos mokslai“ (Index Copernicus, EBSCO host (Academic Search Complete), Gale (Academic OneFile), ProQuest (Ulrich's, Summon), Australia (ERA) 2012 Journal List (ERA ID 34962) skirtas visų specialybių gydytojams, slaugytojams ir kitiems specialistams, spausdina mokslinius straipsnius lietuvių, anglų kalbomis. Reikalavimai straipsniams atitinka mokslo leidiniams keliamus reikalavimus. Žurnalas kioskuose neparduodamas. Žurnalą, kuris leidžiamas kartą per du mènesius, galima užsiprenumeruoti visuose Lietuvos pašto skyriuose, taip pat internetu: www.prenumeruok.It

Prenumeratos kaina nesikeičia: visiems metams - 36 EUR, šešiems mėnesiams - 18 EUR, keturiems mẻnesiams - 12 EUR, dviem mẻnesiams - 6 EUR. Prenumeratos kodas: 5348.

Žurnalo autoriams straipsnių spausdinimas mokamas.

Redakcija 